je riječ o pokretima koji odbacuju ideju potrošnje kao životnoga stila te teže promjeni društvenih vrijednosti zasnovanih na materijalizmu. Spominje i kontrakulturu šezdesetih godina, situacioniste i kritiku društva spektakla te neke od primjera pokreta kao što su Adbusters, Yomango, Enough!, freegani i etički konzumerizam. Na samom kraju autorica daje kritički osvrt na antikonzumerističke pokrete zbog njihova potencijala za perpetuiranjem potrošnje kao alternativnoga načina izražavanja protivljenja potrošnji. Time dolazi do idejne kontradiktornosti, kojom se potvrđuje kako neki od oblika prakse unutar antikonzumerističkih pokreta zapravo mogu postati fundamentalni dio potrošačkoga društva.

Vanja Dergić

doi:10.5559/di.24.3.08

\section{Kornelija Mrnjaus, Nena Rončević i Larisa Ivošević (INTER)KULTURALNA DIMENZIJA U ODGOJU I OBRAzOVANJU}

Filozofski fakultet u Rijeci, Rijeka, 2013., 206 str.

Za interkulturalnost su odgoj i obrazovanje odgovor na postojanje multikulturnih društava i svijest o potrebi stvaranja uvjeta za jednakost pripadnika manjinskih kultura. Od odgoja i obrazovanja očekuje se doprinos razvoju znanja, vještina i stavova koji će učenicima pomoći u razumijevanju i pri- hvaćanju različitosti te izgradnji suživota. Kako bi to bilo moguće, nužno je da temeljni principi interkulturalizma (primjerice otvorenost, aktivno poštivanje različitosti i osiguravanje jednakih mogućnosti) ne budu prisutni isključivo na deklarativnoj razini nego integrirani $u$ sva područja rada škole, uključujući i odnose između učenika i nastavnika. Interkulturne kompetencije nastavnika jedan su od ključnih čimbenika razvoja empatije, solidarnosti i kulturne osjetljivosti kod učenika. Stoga se i primjeri diskriminacije, etnocentrizma i veličanja dominantne kulture, uz istodobno umanjivanje ili prešućivanje doprinosa manjinskih kultura, dijelom mogu objasniti nedovoljnim znanjem i spremnošću nastavnika za upoznavanje i razumijevanje manjinskih kultura učenika te stvaranje okruženja u kojem će se svi osjećati prihvaćeno. Poticaj i podrška u suočavanju s navedenim problemom zasigurno je knjiga (Inter)kulturalna dimenzija u odgoju i obrazovanju autorica Kornelije Mrnjaus, Nene Rončević i Larise Ivošević. U žarištu je knjige razmatranje uloge odgoja i obrazovanja $u$ razvoju interkulturne kompetencije. Knjiga može biti osobito poticajna učiteljima, nastavnicima i stručnim suradnicima u prepoznavanju vlastitih predrasuda, razumijevanju uvjerenja i ponašanja koja ponekad otežavaju prihvaćanje i u načinu ponašanja prema učenicima čija se kulturna raznolikost njeguje.

Sadržaj knjige koncipiran je $\mathrm{u}$ šest poglavlja, koja se tematski mogu svrstati u dvije cjeline: pregled literature o interkulturalnosti, odgoju i obrazovanju te prikaz rezultata empirijskog istraživanja. U Uvo$d u$ autorice određuju problematiku knjige kao pitanje o ulozi odgoja i obrazovanja u razvoju interkulturalnosti u pluralnim društvima. Odgoj i obrazovanje za interkulturalnost i interkulturalna kompetencija dva su ključna pojma knjige. Interkulturalnu kompetenciju definiraju kao skup znanja, vrijednosti, stavova i vještina nužnih za ostvarenje kvalitetnih i prihvatljivih interkulturalnih susreta i razvoj interkulturalnosti u multikulturalnim društvi- 
ma. Radi ostvarenja konceptualne jasnoće i olakšavanja razumijevanja sadržaja, u uvodnom bi dijelu bilo korisno definirati i pojam odgoja i obrazovanja za interkulturalnost. Osim navedenih pojmova, u ovom se području rabe i drugi, primjerice interkulturalni odgoj i obrazovanje, kao najčešći pojam, te interkulturalnost (odnosno interkulturalna dimenzija) u odgoju i obrazovanju, koji se pojavljuje i u naslovu knjige. Autorice se jasno opredjeljuju za termin odgoj i obrazovanje za interkulturalnost, no navođenje srodnih pojmova budi očekivanje pažljiva definiranja i objašnjenja razloga zbog kojih se odabire upravo taj pristup. U drugom dijelu pod nazivom Interkulturalnost - multikulturalnost prikazuju se osnovni pojmovi definirani u znanstvenim radovima i političkim dokumentima koji reguliraju političke i društvene prakse $\mathrm{u}$ navedenoj domeni. Ideje multikulturalnosti i interkulturalnosti prikazuju se uz pomoć njihovih različitosti: postojanje različitosti nasuprot interakciji među kulturama, statična nasuprot dinamičnoj dimenziji višekulturalnosti te kvantitativna nasuprot kvalitativnoj dimenziji različitosti. Interkulturalnost je opisana kao "recipročno djelovanje usmjereno $\mathrm{k}$ međusobnom razumijevanju, dakle dinamičan proces u kojem nije naglasak na vlastitom i tuđem, već na ravnopravnoj interakciji" (str. 55). Nastavnicima i studentima u razumijevanju problematike mogu biti korisna objašnjenja drugih pojmova povezanih s interkulturalnošću: kulturni pluralizam, tolerancija, poštovanje, interkulturalni dijalog, stereotipi, predrasude i diskriminacija. Budući da je razumijevanje interkulturalnosti povezano sa shvaćanjem kulture, u drugom se poglavlju prezentiraju pogledi na kulturu: model ledenoga brijega, Hofstedov model kulturnih dimen- zija, bihevioralne komponente kulture E. T. Halla i M. Reed Hall te model kulture J. Demorgona i M. Molza. Na opći dio o komunikaciji navezuje se razmatranje interkulturalne komunikacije, u kojem se, između ostaloga, opisuje adaptivni model komunikacije C. Dodda. Riječ je o modelu koji, po riječima autorica, opisuje stvaranje nove, tzv. treće kulture, koja proizlazi iz susreta i interakcije dviju kultura. U tom procesu komunikacija se odvija na trima razinama: afektivnoj, kognitivnoj i ponašajnoj. U zadnjem dijelu poglavlja poseban se naglasak stavlja na razumijevanje zapreka koje se javljaju u interkulturnoj komunikaciji. Pozivajući se na L. M. Barnu, autorice navode sljedeće zapreke: pretpostavku o sličnostima zbog nepoznavanja druge kulture, pogrešno prevođenje i razumijevanje, pogrešne interpretacije neverbalnih poruka, stereotipe, etnocentrizam te anksioznost pri susretu s novim i nedovoljno poznatim.

Objašnjenja ključnih pojmova nužnih za razumijevanje problematike odgoja i obrazovanja za interkulturalnost nastavljaju se u trećem poglavlju pod nazivom Interkulturalna kompetencija. Iz mnogih definicija autorice izdvajaju definiciju Kate Berardo, koja interkulturalnu kompetenciju definira kao "sposobnosti za interakciju na djelotvoran i odgovarajući način u različitim interkulturalnim situacijama uspješnim korištenjem interkulturalnih resursa (npr. znanja, vještine, svjesnost i stavovi)" (str. 62). Osim prikaza specifičnih znanja, vještina i stavova kao elemenata interkulturalne kompetencije, $\mathrm{u}$ tom se dijelu opisuju tri tipa modela interkulturalne kompetencije koja predstavljaju različite pristupe njezinu razumijevanju. Komponentni modeli usmjereni su prema navođenju jedne ili nekoliko najvažnijih sposobnosti koje čine interkulturalnu kompetenciju; interakcijski su modeli fokusirani na njezinu interaktivnu prirodu, a razvojni modeli opisuju faze napretka prema boljem razumijevanju i prihvaćanju različitosti. Među opisanim modelima razvoja interkulturalne kompetencije vrijedi istaknuti Bennettov razvojni model 
interkulturalne osjetljivosti. Taj je model vrlo koristan studentima i odgojno-obrazovnim poslenicima u prepoznavanju vlastita odnosa prema kulturnim različitostima. Prema Bennettovu modelu, pojedinci $\mathrm{u}$ susretu s drugim kulturama prolaze kroz šest stadija, koji se svrstavaju u dvije grupe: etnocentrizam i etnorelativizam. Etnocentrističko shvaćanje kulturnih razlika karakteristično je za prva tri stadija: poricanje, obranu i minimiziranje razlika. Etnorelativističko shvaćanje razvija se kroz stadije prihvaćanja, adaptacije i integracije. Osim navedenoga, kako autorice navode, model može biti koristan i za osmišljavanje programa za rad na razvoju interkulturalne osjetljivosti učitelja, nastavnika i studenata, jer pomaže utvrditi stupanj prihvaćanja razlika.

Istraživanje interkulturalne kompetencije četvrto je poglavlje, a donosi prikaz rezultata empirijskog istraživanja kojemu je cilj bio ispitati interkulturalne kompetencije i interkulturalnu osjetljivost budućih pedagoga, nastavnika, učitelja i odgajatelja. Uzorak istraživanja predstavljalo je 523 studenta Filozofskoga fakulteta u Rijeci i Učiteljskoga fakulteta u Rijeci. Istraživanje je provedeno $\mathrm{u}$ akademskoj godini 2011./2012. Kako bi se došlo do podataka o upoznatosti studenata s osnovnim pojmovima i sadržajima s područja odgoja i obrazovanja za interkulturalnost te ispitalo stavove povezane s interkulturalnošću, u istraživanju je upotrijebljen anketni upitnik Interkulturalne kompetencije. Postavljena je hipoteza da ne postoje razlike $\mathrm{u}$ interkulturalnim kompetencijama i interkulturalnoj osjetljivosti s obzirom na spol studenata i fakultet, ali se očekuju razlike s obzirom na prethodnu upoznatost s pojmom interkulturalizam (u navođenju rezultata rabi se pojam interkulturalizam, čime je zadržana terminologija iz originalne verzije upitnika). Većina studenata (njih 78,2\%) susrela se s tim pojmom, ponajviše u medijima (televizija, časopisi, Internet) i tijekom studija. Interkulturalizam ispitanici ponajprije definiraju kao poštivanje i prihvaćanje različitosti, odnosno toleriranje različitosti, dok je aktivna suradnja dviju ili više kultura na svim područjima života na trećem mjestu po zastupljenosti. Autorice napominju da rezultati istraživanja pokazuju kako većina studenata poistovjećuje pojam interkulturalnosti s pojmom multikulturalnosti. U tom je kontekstu zanimljiv podatak da je razumijevanje interkulturalizma kao aktivne suradnje dviju ili više kultura češće kod studenata Filozofskoga fakulteta u odnosu na studente Učiteljskoga fakulteta te kod onih koji su više učili o interkulturalizmu u odnosu na one koji su učili u manjoj mjeri. Osim razlike u znanjima i razumijevanju, između studenata dvaju fakulteta ustanovljene su i razlike u stavovima i svjesnosti o problemu. Studenti Filozofskoga fakulteta skloniji su stavu da odgoj i obrazovanje za interkulturalnost potiče suživot kultura, stavu da potiče borbu protiv etnocentrizma i nacionalizma te stavu da potiče suzbijanje ksenofobičnih stavova. Svjesnost o postojanju kulturnih razlika u okolini veća je kod studentica i kod ispitanika s Učiteljskoga fakulteta. Zanimljiv je podatak da se prema stavu studenata među najpoželjnijim kompetencijama u odgoju i obrazovanju za interkulturalnost nalaze interkulturalna osjetljivost $\mathrm{i}$ vještine nenasilna rješavanja sukoba, dok sposobnost kritičkoga pristupa zbivanjima $u$ društvu gotovo trećina studenata smatra tek osrednje poželjnom kompetencijom $\mathrm{u}$ tom kontekstu. U okviru cjeline prezentiranih rezultata istraživanja vrijedi napomenuti da je hipoteza o postojanju razlika u interkulturalnim kompetencijama s obzirom na prethodnu upoznatost s pojmom i sadržajima potvrđena. Rezultati su pokazali da studenti koji su više učili o interkulturalnosti bolje razumiju značenje pojmova i skloniji su stavovima da se odgojem i obrazovanjem 
potiče suživot među kulturama, odupire etnocentrizmu i nacionalizmu, za razliku od studenata koji nisu učili o interkulturalnosti, što dokazuje razvijenije interkulturalne kompetencije.

U petom poglavlju Odgoj i obrazovanje za interkulturalnost temeljito se opisuju ključni pojmovi i modeli s toga područja. U prvom dijelu poglavlja, pozivanjem na Spajić-Vrkaš, Kukoč i Bašić (2001), odgoj i obrazovanje za interkulturalnost/ multikulturalnost definiraju se kao posebno područje odgoja i obrazovanja koje uključuje niz teorijskih modela, strategija i programa kojima je cilj ostvarivanje razumijevanja i poštivanja vlastite kulture i kulture drugih (originalna terminologija je interkulturalni/multikulturalni odgoj $i$ obrazovanje, prema napomeni na str. 127). Autorice knjige ističu kako odgoj i obrazovanje za interkulturalnost teži prevladavanju pasivne koegzistencije i razvoju održiva načina zajedničkoga života u multikulturnom društvu (str. 126). U nastavku poglavlja navode se ciljevi i oblici odgoja i obrazovanja za interkulturalnost. Stručnjacima iz prakse, kao i studentima, može biti koristan opis faza interkulturalne transformacije škole jer može pomoći procijeniti u kojoj su mjeri interkulturalna načela u konkretnim primjerima integrirana u kulturu škole. Prema P. C. Gorskome, riječ je o šest faza interkulturalne transformacije škole. Prvu fazu karakterizira odsutnost kritičkoga promišljanja postojećih oblika nejednakosti u školi, a kurikul(um) odražava povlaštenost određenih društvenih grupa. Srednje faze karakterizira povremena obradba tema $\mathrm{s}$ interkulturalnim sadržajima bez njihova uključivanja u cjelokupan školski život. Šesta faza predstavlja fazu transformacije školskoga kurikul(um)a tako da svaki as- pekt školskoga života i obrazovanja postaje podjednako dostupan i pravedan za sve učenike. S ciljem sveobuhvatnoga prikaza literature, poglavlje obuhvaća i prikaz interkulturalnih kompetencija nastavnika, opis dimenzija interkulturalnoga kurikul(um)a, opis faza odgoja i obrazovanja za interkulturalnost $\mathrm{u}$ Europi te opis modela odgoja i obrazovanja manjina u Hrvatskoj. Knjiga je iscrpan pregled teorija, koncepata i pristupa povezanih s odgojem i obrazovanjem za interkulturalnost te donosi rezultate provedenoga empirijskog istraživanja i tako ostvaruje postavljene ciljeve. Unatoč vrijednom doprinosu koji se očituje u ostvarenju ciljeva, način obradbe tematike otvara nekoliko pitanja koja se odnose na nejasnoće oko interpretacije rezultata i strukture određenih dijelova knjige. Primjerice, interpretacija rezultata o razlici studenata dvaju fakulteta $\mathrm{u}$ razumijevanju ideje interkulturalizma nije ponuđena te bi se moglo tek nagađati čemu bi se dobivena razlika mogla pripisati. Istraživanjem se ustanovilo da su studenti Filozofskoga fakulteta u odnosu na studente Učiteljskoga fakulteta skloniji stavu kako odgoj i obrazovanje za interkulturalnost potiče suživot kultura, borbu protiv etnocentrizma i nacionalizma i suzbijanje ksenofobičnih stavova. Navedeni su rezultati zanimljivi, dijelom i zato što jasno upućuju na odbacivanje hipoteze o nepostojanju razlika s obzirom na fakultet te navode čitatelja na očekivanje interpretacije. Izostanak tumačenja odnosi se i na rezultat prema kojem je svijest o postojanju kulturnih razlika u vlastitoj okolini veća kod studentica i ispitanika s Učiteljskoga fakulteta. Važno bi također bilo protumačiti rezultat prema kojem gotovo trećina studenata kritički pristup zbivanjima u društvu smatra osrednje poželjnom kompetencijom u kontekstu odgoja i obrazovanja za interkulturalnost.

Drugo se pitanje odnosi na činjenicu da peto poglavlje Odgoj i obrazovanje za interkulturalnost slijedi tek nakon poglavlja o rezultatima empirijskog istraživanja, a prije zaključnoga poglavlja. Definiranjem 
BR. 3

STR. $445-460$

pojmova, opisom faza razvoja škola i kurikul(um)a te navođenjem podjela programa i modela obrazovanja navedeno poglavlje pruža pregled domaće i strane literature o odgoju i obrazovanju za interkulturalnost, pa njegov sadržaj čini svojevrstan temelj za razumijevanje problematike knjige i tematski se nastavlja na početne dijelove o interkulturalnosti i interkulturalnoj kompetenciji. Smještanje toga poglavlja uz početna moglo bi čitateljima pomoći u razumijevanju cjeline problematike, ali i rezultata empirijskoga dijela istraživanja. Osim toga, u poglavlju koje slijedi nakon prikaza empirijskih rezultata očekuje se integracija empirijskoga i teorijskoga dijela kroz prikaz implikacija, smjernica, problema i pitanja koja proizlaze iz rezultata istraživanja i njihove interpretacije. Na taj bi se način naznačila perspektiva razvoja interkulturalnih kompetencija studenata i odgojno-obrazovnih poslenika.

Knjiga (Inter)kulturalna dimenzija u odgoju $i$ obrazovanju teorijskim i empirijskim dijelom ostvaruje zadanu svrhu, a to je isticanje važnosti odgoja i obrazovanja $\mathrm{u}$ razvoju interkulturalne kompetencije. Teorijski dio širinom prikaza temeljnih odrednica područja pridonosi ostvarenju svrhe, a rezultati, između ostalog, pokazuju povezanost interkulturalnih kompetencija s prethodnim učenjem o interkulturalnosti. Pokazalo se da studenti koji su više učili o interkulturalnosti imaju razvijenije interkulturalne kompetencije u odnosu na studente koji su učili manje te pokazuju bolje razumijevanje ideje interkulturalnosti i veću sklonost stavovima da se odgojem i obrazovanjem potiče suživot raznih kultura te odupire etnocentrizmu i nacionalizmu. Navedeni rezultati potvrđuju važnost odgoja i obrazovanja u razvoju interkulturalne kompetencije, odnosno $u$ promicanju poštivanja i prihvaćanja različitosti, kako je istaknuto u zaključku knjige. Jedna od posebnosti knjige jest pružanje sveobuhvatnoga prikaza ideja, modela i koncepata koji su povezani s odgojem i obrazovanjem za interkulturalnost. Takav pristup omogućuje uvid u raznolikost i širinu područja. Koncepti i modeli opisani su tako da ih odgojno-obrazovni poslenici mogu lako povezati sa svakodnevnim situacijama iz prakse, a ideje i pitanja predstavljeni su tako da navode na kritički pristup problemima te pružaju podršku razmatranju promjena u vlastitu radu. Iz navedenih razloga knjiga može biti vrlo vrijedna studentima pedagogije, učiteljskih fakulteta i nastavničkih usmjerenja, kao i učiteljima, nastavnicima te stručnim suradnicima u školama.

Petra Polić

\section{doi:10.5559/di.24.3.09 \\ Ana Petek i Krešimir Petković (ur.) POJMOVNIK JAVNIH POLITIKA}

Fakultet političkih znanosti, Zagreb, 2014., 179 str.

Što su javne politike i tko se njima bavi? Kako izgledaju proces i analiza javnih politika i tko su njezini akteri? Kako proučavati javne politike? Pojmovnik javnih politika urednika Ane Petek i Krešimira Petkovića s Fakulteta političkih znanosti u Zagrebu suočava se s kompleksnom terminologijom javnih politika i objašnjava osamdeset i jednu odrednicu ključnu za razumijevanje praktičnoga i akademskoga svijeta javnih politika. Navedeni pojmovnik prvo je ostvarenje takve vrste u hrvatskom podneblju i pionirski pothvat demistifikacije javnih politika za potrebe struke, akademske zajednice i šire javnosti. Naime, proučavanje javnih politika $u$ 